\title{
Horizontal and vertical movements of the common dolphinfish (Coryphaena hippurus) in La Paz Bay, Mexico
}

\section{Movimientos horizontales y verticales del dorado (Coryphaena hippurus) en la bahía de La Paz, México}

\author{
Cristina Hernández-Tlapale ${ }^{1}$, James Thomas Ketchum² ${ }^{2}$ Emigdio Marín-Enríquez ${ }^{1}$, Arturo Muhlia-Melo ${ }^{*}$ \\ ${ }^{1}$ Centro de Investigaciones Biológicas del Noroeste, Calle IPN 195, Playa Palo de Santa Rita Sur, CP 23096, \\ La Paz, Baja California Sur, México. \\ 2 Pelagios Kakunjá, A.C., La Paz, Baja California Sur, México. \\ * Corresponding author. E-mail: amuhlia04@cibnor.mx
}

\begin{abstract}
The common dolphinfish (Coryphaena hippurus) is an important resource for the sport-fishing industry in Mexico. It is captured incidentally by the eastern Pacific purse-seine tuna fishery and in coastal areas by artisanal fisheries. Although it is considered a highly migratory species, only few studies of its movements are available. In this study, the behavior of the common dolphinfish was analyzed by means of acoustic telemetry at three locations within La Paz Bay (southern Gulf of California) from summer to autumn 2013. Acoustic transmitters were attached to six individuals and they were tracked for periods of up to $48 \mathrm{~h}$. Every hour, vertical profiles of temperature and bathymetry were made. To determine the effect of biotic (sex) and abiotic (water temperature and depth, thermocline depth, hour, and bathymetry) variables on the horizontal and vertical movements of tagged organisms, generalized additive mixed models were applied. The results showed a tendency of horizontal movements to the southwestern zone of the bay; two individuals crossed from the eastern to the western side. The average speed was $0.51 \mathrm{~m} \mathrm{~s}^{-1}$. The vertical movements showed that the individuals spent $80 \%$ of the time above $34 \mathrm{~m}$ depth, of which around $45 \%$ was spent in the upper $10 \mathrm{~m}$ of the water column. During daylight hours they swam in shallow waters (upper $10 \mathrm{~m}$ ) and at night they performed deeper dives (73 m maximum depth). Biotic and abiotic variables influenced both types of movements; however, bathymetry and temperature largely explained fish movements.
\end{abstract}

Key words: horizontal and vertical movements, Coryphaena hippurus, La Paz Bay, acoustic transmitters.

RESUMEN. El dorado (Coryphaena hippurus) es un recurso importante para la pesca deportiva en México. Es capturado incidentalmente por la flota atunera de cerco en el Pacífico oriental y en áreas costeras por la pesca artesanal. Aunque es considerada una especie altamente migratoria, existen pocos estudios sobre sus movimientos. En este estudio se analizaron los movimientos del dorado por medio de telemetría acústica en tres localidades dentro de la bahía de La Paz, parte sur del golfo de California, entre verano y otoño de 2013. Se adhirieron transmisores acústicos a seis individuos y se siguieron durante periodos de hasta $48 \mathrm{~h}$. Cada hora, se hicieron perfiles verticales de temperatura y batimetría. Para determinar el efecto de variables bióticas (sexo) y abióticas (temperatura y profundidad del agua, profundidad de la termoclina, hora y batimetría) sobre los movimientos horizontales y verticales de los organismos marcados, se aplicaron modelos aditivos generalizados mixtos. Los resultados mostraron una tendencia a movimientos horizontales a la zona suroeste de bahía de La Paz; dos movimientos atravesaron la bahía de sureste a suroeste. La velocidad promedio fue de $0.51 \mathrm{~m} \mathrm{~s}^{-1}$. Los movimientos verticales indicaron que los individuos estuvieron por encima de los $34 \mathrm{~m}$ de profundidad el 80\% del tiempo, del cual aproximadamente $45 \%$ estuvieron en los $10 \mathrm{~m}$ superiores. En horas de luz los peces nadaron por arriba de los $10 \mathrm{~m}$ de profundidad y en la noche realizaron inmersiones de hasta $73 \mathrm{~m}$. Las variables bióticas y abióticas influyeron ambos tipos de movimientos; sin embargo, la batimetría y temperatura explicaron en gran parte los movimientos de los peces.

Palabras clave: movimientos horizontales y verticales, Coryphaena hippurus, bahía de La Paz, transmisores acústicos.

\section{INTRODUCTION}

The movement of organisms is defined as a change in their spatial location as a result of a complex interaction between internal factors that promote movement and interpret why, how, when, and where to move and external factors (biotic and abiotic) that affect movement (Nathan et al. 2008). The movements of migratory pelagic fish such as tuna, billfish, and dolphinfish have been shown to be affected by environmental conditions (e.g., currents, changes in temperature and oxygen concentrations with depth), which in

\section{INTRODUCCIÓN}

El movimiento de los organismos es definido como el cambio en su ubicación espacial, consecuencia de una interacción compleja entre factores internos del organismo que promueven su movimiento y que responden al porqué, cómo, cuándo y dónde se mueven y factores externos (bióticos y abióticos) que pudieran influir sobre el movimiento (Nathan et al. 2008). Se ha demostrado que los movimientos de peces pelágicos migratorios como atunes, picudos y dorados son afectados por las condiciones ambientales (e.g., corrientes, 
turn play a key role in determining their permanence and habitat preference (Brill and Lutcavage 2001, Furukawa et al. 2011, Schaefer et al. 2011). It is important to know the movements and habitat preferences of pelagic fish because their vulnerability to fishing is influenced by factors such as the depth they inhabit, travelling speed, residence time in certain areas, and school formation (Brill and Lutcavage 2001).

The common dolphinfish, Coryphaena hippurus Linnaeus, 1758, is a pelagic species distributed in tropical and subtropical seas (Palko et al. 1982). It is ecologically important because it is a top predator in the pelagic ecosystem (Varghese et al. 2013). It is opportunistic (TrippValdez et al. 2010), highly voracious, and has a wide trophic spectrum, and its food habits are closely linked to the epipelagic environment (Aguilar-Palomino et al. 1998).

In Mexico, C. hippurus is distributed along the Pacific coast, from the Baja California Sur region, where it is found year-round (Aguilar-Palomino et al. 1998), to the Gulf of Tehuantepec, off Oaxaca (Alejo-Plata et al. 2011, ZúñigaFlores et al. 2011). This species is reserved for sport fishing within 50 nautical miles measured from the territorial sea baseline (DOF 1995). It is also caught incidentally by the purse-seine and artisanal fisheries (Aguilar-Palomino et al. 1998, Madrid and Beltrán-Pimienta 2001, Martínez-Rincón et al. 2009).

Dolphinfish grow rapidly and have a short life span (Alejo-Plata et al. 2011). Maximum catch sizes of $192 \mathrm{~cm}$ and $30 \mathrm{~kg}$ have been reported for the northwestern coast of Mexico (Madrid and Beltrán-Pimienta 2001). Off Baja California Sur, dolphinfish reach maturity at $80 \mathrm{~cm}$ fork length and during the breeding season (summer-autumn) they are multiple spawners (Zúñiga-Flores et al. 2011).

Little information is available on dolphinfish movements. Studies have analyzed their movements around floating fish aggregating devices (Girard et al. 2007, Taquet et al. 2007) and described their movements in the open sea (Furukawa et al. 2011, 2014; Merten et al. 2014a, 2014b, 2014c). These studies indicate that dolphinfish tend to stay above the thermocline (Furukawa et al. 2011) and that they are able to perform directed movements and return to their point of origin (Girard et al. 2007). In coastal water bodies, however, many aspects relating to their movements, use of habitat, and environmental preferences are still unknown. The objective of this study was to identify the biotic and abiotic factors that influence the fine-scale horizontal and vertical movements (every $16 \mathrm{~min}$ ) of dolphinfish in a short time frame (up to $48 \mathrm{~h}$ ) in a coastal water body in the Gulf of California.

\section{MATERIALS AND METHODS}

\section{Study area and tagging}

This study was carried out in the southwestern part of La Paz Bay (LPB), Baja California Sur, Mexico (fig. 1). Eight dolphinfish were caught by hook and line at three localities cambios de temperatura y concentración de oxígeno con la profundidad), que a su vez son transcendentales en la determinación de su permanencia y preferencia de hábitat (Brill y Lutcavage 2001, Furukawa et al. 2011, Schaefer et al. 2011). Es importante conocer cómo los peces pelágicos rigen sus movimientos y preferencias de hábitat ya que se ha reportado que la vulnerabilidad de estos peces a la pesca es influenciada por factores como la profundidad que habitan, la velocidad a la que viajan, el tiempo de residencia en determinadas áreas y la formación de cardúmenes (Brill y Lutcavage 2001).

El dorado, Coryphaena hippurus Linnaeus, 1758, es una especie epipélagica que se distribuye en mares tropicales y subtropicales (Palko et al. 1982). Es ecológicamente importante por ser un depredador tope en el ecosistema pelágico (Varghese et al. 2013). Es un depredador oportunista (TrippValdez et al. 2010), altamente voraz, con un espectro trófico amplio y de hábitos alimenticios estrechamente relacionados con el ambiente epipelágico (Aguilar-Palomino et al. 1998).

En las costas mexicanas del Pacífico, C. hippurus se ha registrado desde Baja California Sur, donde permanece todo el año (Aguilar-Palomino et al. 1998), hasta el golfo de Tehuantepec, frente a las costas de Oaxaca (Alejo-Plata et al. 2011, Zúñiga-Flores et al. 2011). En México, el dorado está reservado a la pesca deportiva dentro de las 50 millas náuticas medidas a partir de la línea base de costa donde se define el mar territorial (DOF 1995). Además, forma parte de la captura incidental de la pesquería artesanal y de cerco (Aguilar-Palomino et al. 1998, Madrid y Beltrán-Pimienta 2001, Martínez-Rincón et al. 2009).

El dorado se caracteriza por tener una corta vida y un rápido crecimiento (Alejo-Plata et al 2011). Las tallas máximas de captura que se han registrado para la costa noroccidental mexicana son de $192 \mathrm{~cm}$ y $30 \mathrm{~kg}$ (Madrid y Beltrán-Pimienta 2001). Se ha documentado que en aguas frente a Baja California Sur estos peces alcanzan una talla de madurez poblacional de $80 \mathrm{~cm}$ de longitud furcal y durante la época reproductiva (verano-otoño) son desovadores múltiples (Zúñiga-Flores 2011).

La información sobre los movimientos del dorado aún es escasa y principalmente describe los movimientos con relación a la presencia de dispositivos agregadores de peces (Girard et al. 2007, Taquet et al. 2007) y los movimientos en mar abierto (Furukawa et al. 2011, 2014; Merten et al. 2014a, $2014 b, 2014 c)$. Se ha descrito que el dorado generalmente permanece a una profundidad por encima de la termoclina (Furukawa et al. 2011) y que sus movimientos pueden regresar al punto de marcado (Girard et al. 2007). Sin embargo, aún se desconocen muchos aspectos sobre sus movimientos, uso del hábitat y preferencias ambientales que permitan identificar hábitats esenciales para la especie en aguas costeras. El objetivo de este estudio fue identificar factores bióticos y abióticos que influyen sobre los movimientos horizontales y verticales del dorado a una fina escala (cada $16 \mathrm{~min}$ ) y en un corto tiempo (hasta $48 \mathrm{~h}$ ) en un cuerpo de agua costero en el golfo de California. 
within the bay (Califin [north], Quelele, and Pichilingue) in September and October 2013. Two of these individuals were only used for a few hours to test the tracking equipment.

Each captured individual was placed on a wet towel on the boat's deck and the eyes were covered with a wet cloth to reduce stress caused by illumination. A plastic hose connected to an underwater pump was inserted into the mouth to provide a continuous flow of seawater and facilitate oxygenation of the gills. Each fish was measured for fork length and total length, and sexed based on the sexual dimorphism described by Palko et al. (1982): the males are more distinctive than the females because they develop a bony ridge on the head.

Each individual was fitted with an external V16-TP continuous acoustic transmitter $(16 \mathrm{~mm}$ diameter, $71 \mathrm{~mm}$ wide, $11 \mathrm{~g}$ weight in water; VEMCO, Halifax, Canada) equipped with a temperature sensor (accuracy $0.12{ }^{\circ} \mathrm{C}$ ) and depth sensor (accuracy $0.9 \mathrm{~m}$ ). The transmitters were attached by passing a plastic strap using a stainless steel needle through $1 \mathrm{~cm}$ of muscle near the base of the caudal fin. The entire capture and tagging process did not take more than $7 \mathrm{~min}$.

\section{Acoustic monitoring}

Each individual was actively tracked. The boat was outfitted with a VH110 directional hydrophone and a VR100 receiver (VEMCO) to detect the transmissions from the acoustic tags every $2000 \mathrm{~ms}$. The receiver recorded water temperature, depth, signal strength $(\mathrm{dB})$ from the transmitter, and the boat's geographic position. Range tests were performed before initiating the continuous tracking. The detection range of the receiver was tested relative to different distances and depths of the acoustic trasmitter. The range test revealed that the maximum detection distance was $1260 \mathrm{~m}$ at depths of 0.5 and $10.0 \mathrm{~m}$. During each tracking period, the bathymetry was measured with a GPSMAP 431 s sounder (Garmin International, Olathe, KS), and hourly CTD casts (YSI CastAway 11B111032, YSI, Yellow Springs, OH) were conducted to collect water samples and construct vertical temperature profiles.

\section{Treatment of data}

The data recorded every $2000 \mathrm{~ms}$ by the receiver were subjected to the process proposed by Ketchum et al. (2014) to eliminate temporal autocorrelation and false data, and time series with 16 min intervals were obtained. Maps were then elaborated in ArcMap 10 (Esri, 2010) for each track. The minimum distance from shore was calculated in ArcView (2010) based on the geographic position of the fish along each track. The data used to statistically assess the horizontal and vertical movements were filtered to obtain 1-min values in order to use as much information as possible.

Thermocline depth was calculated based on the Brunt-Väisälä frequency. The thermocline is located at the

\section{MATERIALES Y MÉTODOS}

\section{Área de estudio y marcado}

El estudio se llevó a cabo en el suroeste de la bahía de La Paz (BLP), Baja California Sur, México (fig. 1). Un total de ocho dorados fueron capturados con caña de pesca y anzuelo en tres localidades (Califín [norte], Quelele y Pichilingue) dentro de BLP entre septiembre y octubre de 2013. Dos individuos fueron utilizados por unas horas para probar el equipo de seguimiento.

Una vez capturado un pez, se le colocó en la cubierta de la embarcación sobre una toalla húmeda, se le cubrieron los ojos con una franela para reducir el estrés por iluminación y se le insertó en la boca una manguera de plástico conectada a una bomba sumergible para proveer de un flujo continuo de agua de mar y permitir la oxigenación de las branquias. Para cada individuo, se midió la longitud furcal y total, y se determinó el sexo con base en el dimorfismo sexual descrito por Palko et al. (1982), según el cual los machos se diferencian de las hembras por desarrollar una cresta ósea en la cabeza.

A cada individuo se le colocó de manera externa un transmisor acústico V16TP de tipo continuo con sensores internos de temperatura (precisión $0.12^{\circ} \mathrm{C}$ ) y profundidad (precisión $0.9 \mathrm{~m})(16 \mathrm{~mm}$ de diámetro, $71 \mathrm{~mm}$ de ancho, $11 \mathrm{~g}$ de peso en agua; VEMCO, Halifax, Canadá) atravesando un cincho de plástico con una aguja de acero inoxidable en $1 \mathrm{~cm}$ de músculo cerca de la base de la aleta caudal. Todo el proceso de captura y marcado se realizó en un tiempo no mayor que $7 \mathrm{~min}$.

\section{Monitoreo acústico}

Se dio seguimiento activo de manera individual a cada organismo. La embarcación fue equipada con un hidrófono direccional VH110 y un receptor acústico VR100 (VEMCO) para detectar las transmisiones acústicas cada $2000 \mathrm{~ms}$ desde el pez. El receptor registró la profundidad, la temperatura del agua, la fuerza de la señal $(\mathrm{dB})$ del transmisor acústico y la posición geográfica de la lancha. Previo a los seguimientos continuos se hizo una prueba de rango para los receptores. Se probó el alcance de detección del receptor con respecto a diferentes distancias y profundidades del transmisor acústico. La prueba de rango mostró que la distancia máxima de detección fue de $1260 \mathrm{~m}$ a profundidades de 0.5 y $10.0 \mathrm{~m}$. Durante cada seguimiento, se registró la batimetría del área de seguimiento con una ecosonda GPSMAP 431s (Garmin International, Olathe, KS). También, se realizaron lances de un perfilador o CTD (YSI CastAway 11B111032, YSI, Yellow Springs, $\mathrm{OH}$ ) en la columna de agua cada hora a lo largo de todo el seguimiento para hacer perfiles verticales de temperatura. 

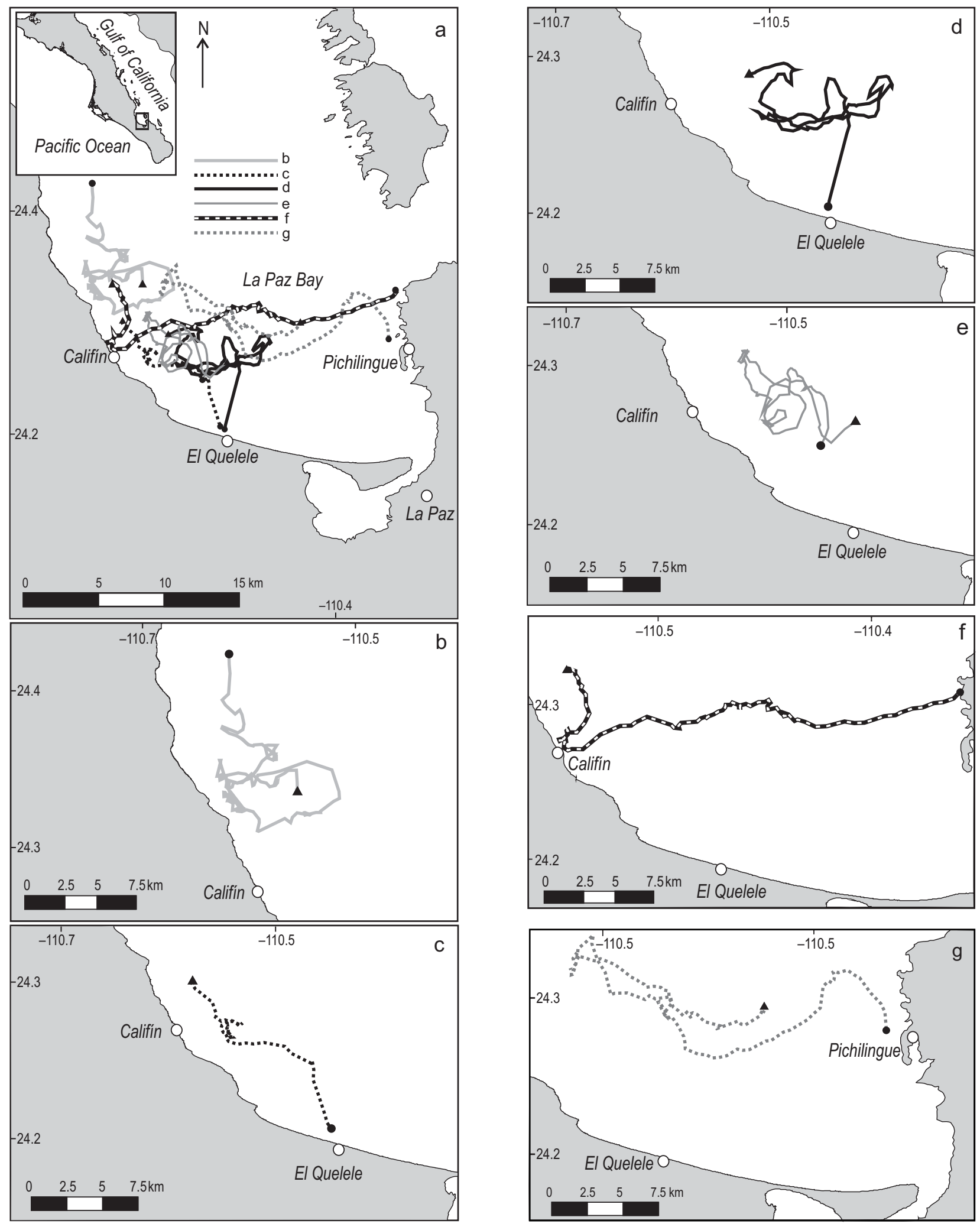

Figure 1. (a) Study area and tracking of six common dolphinfish (Coryphaena hippurus) at three locations in La Paz Bay (Mexico): (1) north of Califín, (2) Quelele, and (3) Pichilingue. (b-g) Tracks 1-6, respectively; circles indicate the start and triangles the end point.

Figura 1. (a) Área de estudio y rutas de movimiento de seis dorados (Coryphaena hippurus) en tres sitios dentro de la bahía de La Paz (México): (1) norte de Califín, (2) Quelele y (3) Pichilingue. (b-g) Seguimientos 1-6, respectivamente; los círculos indican el inicio del seguimiento y los triángulos el final. 
depth where stabilization occurs in the vertical displacement frequency of a water mass over a density gradient in the water column (Cushman-Roisin and Beckers 2009).

\section{Models}

Generalized additive mixed models (GAMMs) were used to determine the factors that influence the horizontal and vertical movements of $C$. hippurus. Two models were constructed to assess the movements. In the first model for horizontal movements, the response variable was the minimum distance from shore of the tagged fish and the explanatory variables were bathymetry of the area, water temperature recorded by the accoustic transmitters, time of day (hour), and gender. In the second model for vertical movements, the response variable was depth and the explanatory variables were water temperature, bathymetry, thermocline depth, and gender. All the explanatory variables except for gender were continuous. For both models the random effect corresponds to each individual (table 1). Considering the nature of the data for the response variables, the Poisson family was used for the statistical analysis (Zuur et al. 2009).

To determine the model that best fit the data, the methodology used by Papastamatiou et al. (2013) was followed. The models were initially constructed considering the explanatory variables individually. These variables were all then incorporated depending on the contribution of each variable to the variability in the data. The best model was chosen based on standard selection criteria (adjusted coefficient of determination $\left[R^{2}\right]$, Akaike information criterion, and Bayesian information criterion). The model assumptions were verified in the residual plots.

To analyze the effect of the explanatory variables on the response variable after fitting the model, main-effects plots were generated. The effect line is interpreted as follows: values $>0$ on the $y$-axis have an effect on the response variable regarding the specific values of the explanatory variable. The GAMMs were built using the R 3.0.3 software (R Core Team 2014) and the mgcv package (Wood 2006).

\section{RESULTS}

Six individuals of $C$. hippurus (three males and three females) were tracked for a period of more than $20 \mathrm{~h}$. They ranged in fork length from 67.0 to $83.5 \mathrm{~cm}$ and, based on the size at sexual maturity reported by Zúñiga-Flores et al. (2011), they were juveniles. Monitoring of three of them (tracks 2, 5, and 6; table 2) concluded when the position of the fish did not change and the depth sensor reading coincided with the echosounder seafloor depth reading. The average distance covered per hour was $1.59 \mathrm{~km}( \pm 0.106$, standard error), at a mean speed of $0.51 \mathrm{~m} \mathrm{~s}^{-1}( \pm 0.51)$ (table 2). The mean depth of the thermocline, when detected, was $34 \mathrm{~m}( \pm 0.12)$.

\section{Tratamiento de datos}

A los datos registrados por el receptor cada $2000 \mathrm{~ms}$ se les aplicó la metodología de Ketchum et al. (2014) para eliminar la autocorrelación temporal y los datos falsos, y se obtuvieron series de tiempo con intervalos de 16 min. Después se elaboraron mapas en ArcMap 10 (Esri, 2010) para cada uno de los seguimientos. La distancia mínima a la costa fue calculada en ArcView (Esri, 2010) con base en la posición geográfica del dorado en cada uno de los seguimientos. La base de datos usada para evaluar estadísticamente los movimientos horizontales y verticales fue filtrada a $1 \mathrm{~min}$ para utilizar la mayor información posible.

La profundidad de la termoclina se calculó con base en la frecuencia de Brunt-Väisälä. La termoclina se ubica en la profundidad donde se estabiliza la frecuencia vertical de desplazamiento de una masa de agua sobre un gradiente de densidades en la columna de agua (Cushman-Roisin y Beckers 2009).

\section{Modelos}

Para determinar qué factores influyeron sobre los movimientos horizontales y verticales de los dorados, se utilizaron modelos aditivos generalizados mixtos. Se construyeron dos modelos para evaluar los movimientos. Para el modelo referente a los movimientos horizontales, la variable de respuesta fue la distancia más cercana a la costa a la cual se encontró el pez y las variables explicativas seleccionadas fueron la batimetría de la zona, la temperatura del agua que registraron los transmisores acústicos, la hora del día y el género. Para el modelo referente a los movimientos verticales, la variable de respuesta fue la profundidad a la cual los peces se desplazaron y las variables explicativas fueron temperatura del agua, batimetría, hora del día, profundidad de la termoclina y género. Todas las variables explicativas fueron continuas, a excepción de género. Para ambos modelos, el efecto al azar corresponde a cada individuo (tabla 1). Por la naturaleza de los datos de las variables de respuesta, se usó la familia Poisson para el análisis estadístico (Zuur et al. 2009).

Para encontrar el mejor ajuste de los modelos a los datos, se siguió la metodología de Papastamatiou et al. (2013). Los modelos se construyeron evaluando primero de manera individual las variables explicativas y después incorporándolas en conjunto según la contribución de cada una de ellas a la varianza de los datos. El mejor modelo se basó en los criterios de selección estándar (coeficiente de determinación ajustado $\left[R^{2}\right]$, criterio de información de Akaike, criterio de información bayesiano). Los supuestos de los modelos se comprobaron en los gráficos de los residuales.

Para analizar el efecto de las variables explicativas sobre la variable de respuesta después de ajustar el modelo, se realizaron los gráficos de efecto. La línea de efecto se interpreta como sigue: valores $>0$ en el eje $y$ tienen un efecto sobre la variable de respuesta en los valores específicos 


\section{Horizontal movements}

The majority of the horizontal movements occurred in a shallow zone (1-80 m depth) in the southwestern part of LPB (fig. 1). Two fish tagged in the southeastern part crossed almost the entire bay to the opposite side (tracks 5 and 6). The other four moved in different directions, two of them northwestwards (tracks 2 and 3), one southwards (track 1), and one remained close to where it was captured (track 4).

The model that best fit the data for the horizontal movements was:

$$
\begin{gathered}
\text { DistShore } \left.=\alpha+f_{1} \text { (bathymetry }\right)+f_{2}(\text { water temperature })+ \\
f_{3}(\text { hour })+\text { gender }+(1 / \text { track })
\end{gathered}
$$

where DistShore is the minimum distance from shore, $\alpha$ is the intercept, $f_{n}$ is the smooth function for each explanatory variable, and ( $1 /$ track) is the random effect of the individuals. All the explanatory variables were significant at $P \leq 0.05$. The model explained $45 \%\left(R^{2}=0.45\right.$, table 2$)$ of the total deviance. Bathymetry and water temperature were the most important variables, followed by hour and gender (table 1).

The plots showing the effect of the explanatory variables on the minimum distance from shore indicate that there is greater likelihood of the fish moving away from the shore when the bathymetry is deep (40-120 m) and the water temperature is $27-30^{\circ} \mathrm{C}$, and during the night $(23: 00$ and $6: 00 \mathrm{~h})$. Females moved further away from the shore than males (fig. 2).

\section{Vertical movements}

The depth range for all the tracks was 1 to $73 \mathrm{~m}$. The tagged fish remained $80 \%$ of the time in the mixed layer, that is, above $34 \mathrm{~m}$ depth, but $45 \%$ of the time was spent in the upper $10 \mathrm{~m}$ (fig. 3a). The fish spent $70 \%$ of their time in areas where water temperature was $27-28^{\circ} \mathrm{C}$ (fig. $3 b$ ). Differences were observed between the diurnal and nocturnal movement patterns. The individuals remained closer to the surface during daylight hours than during the night, as shown by the fragment of the depth time series for track 4 (fig. 4), and a greater number of vertical immersions from the surface to depths of more than $70 \mathrm{~m}$ occurred during the night.

The best-fit model for the vertical movements was:

$$
\begin{gathered}
\text { Fish depth } \left.=\alpha+f_{1}(\text { water temperature })+f_{2} \text { (bathymetry }\right)+ \\
\left.f_{3} \text { (hour }\right)+f_{4}(\text { thermocline depth })+\text { gender }+(1 / \text { track })
\end{gathered}
$$

The explanatory variables were significant at $P<0.05$. The model explained $64 \%$ of the deviance $\left(R^{2}=0.6\right.$, table 1$)$. The most important explanatory variables were water temperature and bathymetry, followed by hour, thermocline depth, and gender.

The individuals are likely to remain at a greater depth when water temperature is less than $28^{\circ} \mathrm{C}$, when bottom que corresponden a la variable explicativa. Los modelos aditivos generalizados mixtos se realizaron con el software $\mathrm{R}$ 3.0.3 (R Core Team 2014) usando el paquete mgcv (Wood 2006).

\section{RESUlTADOS}

Se consideraron sólo seis seguimientos de individuos de C. hippurus (tres machos y tres hembras) con registros de más de $20 \mathrm{~h}$, con un intervalo de tallas de entre $67.0 \mathrm{y}$ $83.5 \mathrm{~cm}$ de longitud furcal y que, según la talla de madurez sexual reportada por Zúñiga-Flores et al. (2011), fueron juveniles. Tres seguimientos se dieron por terminados (seguimientos 2, 5 y 6; tabla 2) cuando la posición del dorado no cambió y la lectura del sensor de profundidad de los transmisores acústicos coincidió con el fondo marino también registrado por la ecosonda. La distancia promedio recorrida por hora fue de $1.59 \mathrm{~km}( \pm 0.106$, error estándar) a una velocidad promedio de $0.51 \mathrm{~m} \mathrm{~s}^{-1}( \pm 0.51)$ (tabla 2). La profundidad promedio de la termoclina, cuando fue detectada, fue de $34 \mathrm{~m}( \pm 0.12)$.

\section{Movimientos horizontales}

Los movimientos de los dorados marcados se concentraron en una zona somera (1-80 $\mathrm{m}$ de profundidad) del suroeste de BLP (fig. 1). Dos peces marcados en el sureste cruzaron hacia el extremo opuesto, atravesando casi toda la bahía (seguimientos 5 y 6), mientras que los otros cuatro se movieron en distintas direcciones. Dos de estos cuatro individuos hicieron movimientos hacia el noroeste (seguimientos 2 y 3 ), uno hacia el sur (seguimiento 1) y uno concentró sus movimientos cerca del lugar de captura (seguimiento 4).

El modelo ajustado para los movimientos horizontales fue el siguiente:

$$
\begin{gathered}
\text { DistCosta } \left.=\alpha+f_{1}(\text { batimetría })+f_{2} \text { (temperatura del agua }\right)+ \\
f_{3}(\text { hora })+\text { género }+(1 / \text { seguimiento })
\end{gathered}
$$

donde DistCosta es la distancia mínima a la costa, $\alpha$ es el intercepto, $f_{n}$ es la función suavizante para cada una de las variables explicativas y (1/seguimiento) es el efecto azaroso de los individuos. Todas las variables explicativas fueron significativas a $P \leq 0.05$. El modelo explicó un $45 \%\left(R^{2}=0.45\right.$, tabla 2) de la devianza total. La batimetría y la temperatura del agua fueron las variables más importantes, seguidas de la hora y género (tabla 1 ).

Los gráficos de efectos de las variables explicativas sobre la distancia más cercana a la costa muestran que la probabilidad de que los dorados se alejen de la costa es cuando la batimetría es profunda (40-120 m), la temperatura del agua es entre 27 y $30^{\circ} \mathrm{C}$ y durante la noche $(23: 00$ y 6:00 h). Las hembras se alejaron más de la costa que los machos (fig. 2). 
Table 1. Generalized additive mixed models to assess the effects of the explanatory variables on the movements of Coryphaena hippurus: $R^{2}$, adjusted coefficient of determination; AIC, Akaike information criterion; BIC, Bayesian information criterion. The model that best fits the data is shown in bold.

Tabla 1. Modelos aditivos generalizados mixtos para evaluar el efecto de las variables explicativas sobre los movimientos de Coryphaena hippurus: $R^{2}$, coeficiente de determinación ajustado; AIC, criterio de información de Akaike; BIC, criterio de información bayesiano. El mejor ajuste del modelo se muestra en negritas.

\begin{tabular}{|c|c|c|c|}
\hline Horizontal model & $R^{2}(\%)$ & AIC & $\mathrm{BIC}$ \\
\hline 2. Hour & 0.01 & $10,936.68$ & $10,972.25$ \\
\hline 4. Bathymetry & 0.30 & $4,828.26$ & $4,863.80$ \\
\hline 5. Bathymetry + water temperature & 0.31 & $3,806.80$ & $3,856.63$ \\
\hline 8. Bathymetry + water temperature + hour & 0.31 & $3,520.20$ & $3,584.30$ \\
\hline 9. Bathymetry + water temperature + gender & 0.43 & $3,806.47$ & $3,863.38$ \\
\hline 10. Bathymetry + water temperature + hour + gender & 0.45 & $3,519.88$ & $3,598.13$ \\
\hline \multicolumn{4}{|l|}{ Vertical model } \\
\hline 4. Bathymetry & 0.11 & $20,837.79$ & $20,873.36$ \\
\hline 5. Gender & 0.05 & $21,632.06$ & $21,660.51$ \\
\hline 6. Water temperature + bathymetry & 0.30 & $18,660.07$ & $18,709.87$ \\
\hline 7. Water temperature + hour & 0.33 & $19,488.10$ & $19,537.90$ \\
\hline 8. Water temperature + thermocline depth & 0.29 & $18,987.95$ & $19,037.75$ \\
\hline 9. Water temperature + gender & 0.44 & $19,419.11$ & $19,461.79$ \\
\hline 10. Water temperature + bathymetry + thermocline depth & 0.28 & $18,661.10$ & $18,725.47$ \\
\hline 11. Water temperature + bathymetry + gender & 0.50 & $18,657.80$ & $18,714.71$ \\
\hline 12. Water temperature + bathymetry + hour & 0.41 & $18,506.04$ & $18,570.07$ \\
\hline
\end{tabular}

Table 2. Fork length, age, and sex of six tagged individuals of Coryphaena hippurus and tracking data. SE, standard error.

Tabla 2. Longitud furcal, edad y sexo de seis individuos de Coryphaena hippurus marcados y datos de seguimiento. SE, error estándar.

\begin{tabular}{|c|c|c|c|c|c|c|c|c|c|}
\hline $\begin{array}{c}\text { Track } \\
\text { number }\end{array}$ & $\begin{array}{l}\text { Fork } \\
\text { length } \\
(\mathrm{cm})\end{array}$ & $\begin{array}{l}\text { Age } \\
\text { (year) }\end{array}$ & Sex & $\begin{array}{c}\text { Tracking } \\
\text { period } \\
(\mathrm{dd} / \mathrm{mm} / \text { year })\end{array}$ & $\begin{array}{l}\text { Tracking } \\
\text { duration } \\
\text { (h) }\end{array}$ & Start location & $\begin{array}{c}\text { Total } \\
\text { distance } \\
(\mathrm{km})\end{array}$ & $\begin{array}{c}\text { Average } \\
\text { distance } \\
\text { per hour } \\
(\mathrm{km})\end{array}$ & $\begin{array}{l}\text { Mean } \\
\text { speed } \\
\left(\mathrm{m} \mathrm{s}^{-1}\right)\end{array}$ \\
\hline 1 & 83.5 & 0.90 & $\mathrm{M}$ & $01-03 / 09 / 2013$ & 48 & North of Califín & 97.66 & 2.03 & 0.77 \\
\hline 2 & 67.0 & 0.53 & $\mathrm{~F}$ & $26-27 / 09 / 2013$ & $22 *$ & Quelele & 29.29 & 1.33 & 0.35 \\
\hline 3 & 72.0 & 0.62 & $\mathrm{~F}$ & $28-30 / 09 / 2013$ & 47 & Quelele & 72.13 & 1.53 & 0.51 \\
\hline 5 & 82.0 & 0.86 & $\mathrm{~F}$ & $08-10 / 10 / 2013$ & $38^{*}$ & Pichilingue & 60.81 & 1.60 & 0.40 \\
\hline \multirow[t]{3}{*}{6} & 72.0 & 0.67 & M & $22-24 / 10 / 2013$ & $47 *$ & Pichilingue & 81.69 & 1.73 & 0.58 \\
\hline & & & & & & & Average & 1.59 & 0.51 \\
\hline & & & & & & & SE & 0.106 & 0.06 \\
\hline
\end{tabular}

* Prematurely finished 

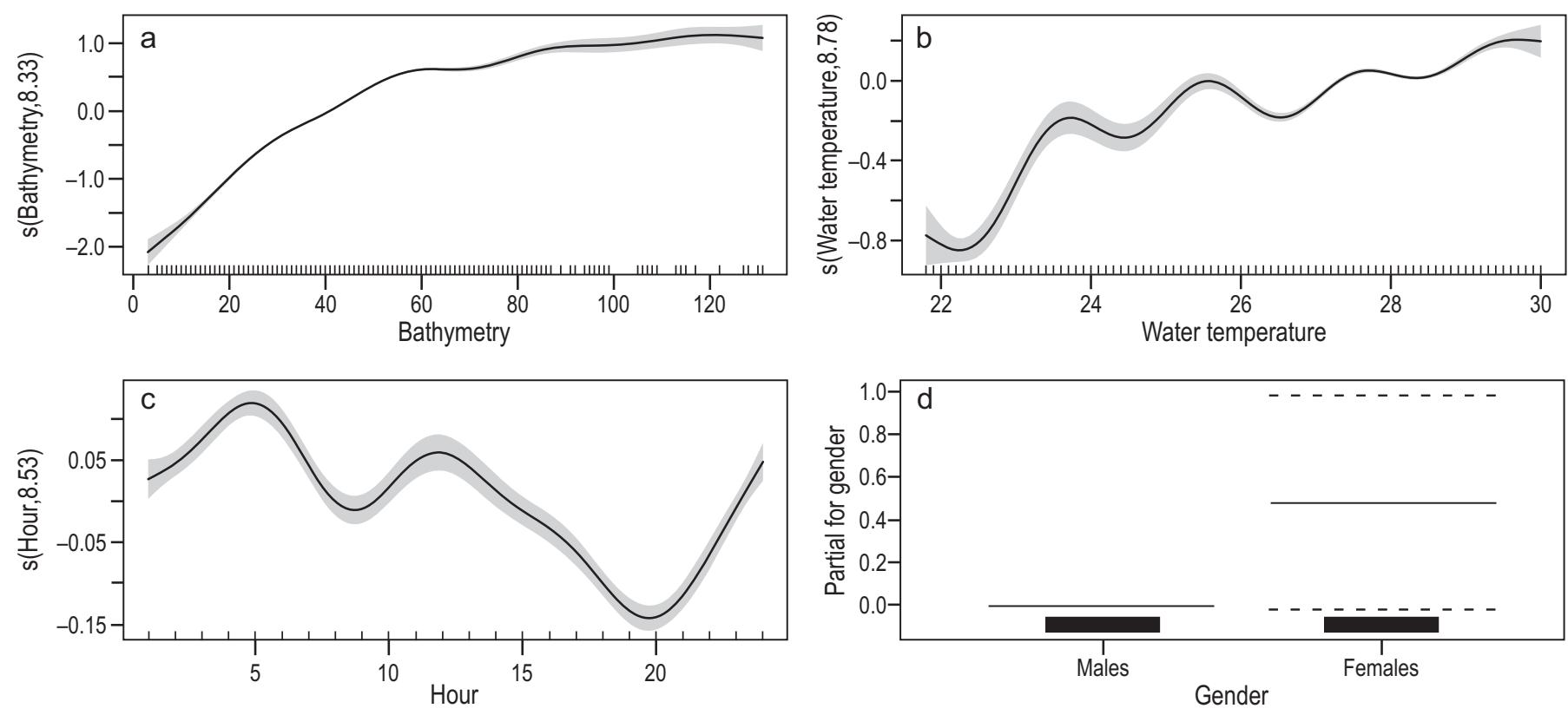

Figure 2. Generalized additive mixed models for the horizontal movements of Coryphaena hippurus. Plots show the effect of the explanatory variables (bathymetry, water temperature, hour, and gender) on the response variable (distance from shore). In (a-c), black tick marks above the $x$-axes indicate the distribution of data and the $y$-axes show the response variable on the scale of the linear predictor; the shaded areas indicate the standard error. In (d), the bars above the $x$-axis indicate the cumulative data for each gender, the thin horizontal lines indicate the value for the response variable (distance from shore) on the linear predictor scale, and the horizontal dashed lines indicate the standard error.

Figura 2. Modelos aditivos generalizados mixtos para los movimientos horizontales de Coryphaena hippurus. Las gráficas muestran el efecto de las variables explicativas (batimetría, temperatura del agua, hora y género) sobre la variable de respuesta (distancia de la costa). En (a-c), las líneas verticales sobre los ejes $x$ indican la distribución de datos y los ejes $y$ muestran el valor de la variable de respuesta en la escala del predictor lineal; las áreas sombreadas indican el error estándar. En (d), las barras negras sobre el eje $x$ representan el acumulativo de los datos de cada género, las líneas horizontales delgadas representan el valor de la variable de respuesta (distancia de la costa) en escala del predictor lineal y las líneas horizontales discontinuas indican el error estándar.
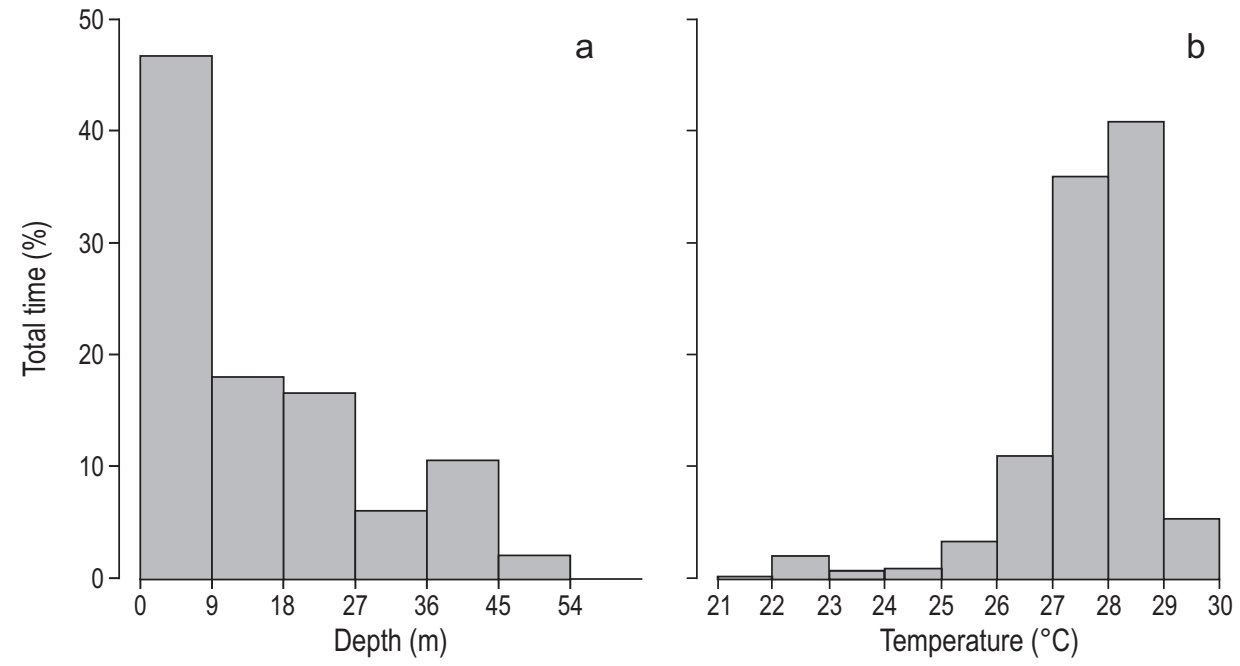

Figure 3. (a) Depth and (b) temperature along the tracks of Coryphaena hippurus.

Figura 3. (a) Profundidad y (b) temperatura a lo largo de las rutas de movimiento de Coryphaena hippurus. 
depth is greater than $30 \mathrm{~m}$, between 15:00 and 3:00 h, and when the thermocline depth is between 40 and $60 \mathrm{~m}$. Females dove deeper than males (fig. 5).

\section{DISCUSSION}

The horizontal and vertical movements of C. hippurus in LPB were identified in relation to biotic (sex) and abiotic (water temperature recorded by the acoustic transmitters, bathymetry, thermocline depth, and hour) factors. Eight juvenile dolphinfish were tagged, but only six were tracked for a maximum period of $48 \mathrm{~h}$ in summer. All the tagged individuals remained inside LPB and most of their horizontal movements occurred in a shallow area $(1-80 \mathrm{~m})$ in the southwestern part where water temperature was $27-29^{\circ} \mathrm{C}$. These temperatures coincide with other reported preferential temperatures (Palko et al. 1982, Campos et al. 1993, Massutí and Morales-Nin 1995, Farrell et al. 2014).

Two individuals tagged in the southeastern part of LPB, one male and one female, showed similar movements, both crossing the bay to the opposite side. The other four individuals moved in different directions but did not stray far from their capture site. Merten et al. (2014a, 2014b) reported that movement directions and rates of dolphinfish tagged in the western Atlantic depend on the latitude, longitude, and distance from shore released, but do no elucidate further on this behavior.

In our study, the tagged dolphinfish exhibited vertical movements in the upper $30 \mathrm{~m}$ of the water column, above the thermocline (when it was detected). This coincides with the epipelagic nature of these fish and with other reports that mention that they spend most of their time at the surface (Furukawa et al. 2011, Merten et al. 2014c). This habitat preference has been linked to the distribution of their food in the water column (Furukawa et al. 2011, Merten et al. 2014c). Several studies on the feeding habits of this species have reported that epipelagic prey distributed in the surface strata of the water column are an important component of the diet (Aguilar-Palomino et al. 1998, Olson and GalvánMagaña 2002, Tripp-Valdez et al. 2010). Moreover, thermal stratification in the sea can act as a physical barrier that prevents the prey from escaping. Gray and Kingsford (2003) suggested that the most important stratum for trophic interactions among fish larvae and zooplankton is the upper $30 \mathrm{~m}$ of the water column, regardless of the position of the thermocline. In the present study, the tagged dolphinfish spent most of their time above $30 \mathrm{~m}$ depth.

Furukawa et al. $(2011,2014)$ suggested that dolphinfish spend most of their time in shallow waters to avoid rapid changes in temperature and thus minimize energy use by remaining in isothermal conditions above the thermocline. Our findings indicate that the dolphinfish occasionally crossed the thermocline (when it was detected), a behavior also reported by Furukawa et al. (2011) and Merten et al. (2014c).

\section{Movimientos verticales}

El intervalo de profundidad para todos los seguimientos fue de 1 a $73 \mathrm{~m}$. Los organismos permanecieron el $80 \%$ del tiempo dentro de la capa de mezcla, es decir, por arriba de los $34 \mathrm{~m}$ de profundidad; sin embargo, permanecieron un elevado porcentaje de tiempo (45\%) en los primeros $10 \mathrm{~m}$ (fig. 3a). Los individuos marcados invirtieron más del $70 \%$ del tiempo en aguas con temperaturas de entre 27 y $28^{\circ} \mathrm{C}$ (fig. 3b). Los movimientos verticales indicaron que los individuos se movieron en estratos más superficiales durante las horas de luz en comparación con la noche, como se puede observar en el fragmento de la serie de tiempo de profundidad para el seguimiento 4 (fig. 4); además, se observó un mayor número de inmersiones verticales desde la superficie hasta más de $70 \mathrm{~m}$ de profundidad durante la noche.

El modelo resultante para los movimientos verticales fue el siguiente:

Profundidad del pez $=\alpha+f_{1}$ (temperatura del agua) + $f_{2}$ (batimetría $)+f_{3}($ hora $)+f_{4}($ profundidad de termoclina $)+$ género $+(1 /$ seguimiento $)$

Las variables explicativas evaluadas fueron significativas a $P<0.05$. La devianza explicada fue de $64 \%,\left(R^{2}=0.6\right.$, tabla 1). Las variables explicativas con mayor peso fueron la temperatura del agua y la batimetría, seguidas de la hora del día, la profundidad de la termoclina y el género. La probabilidad de que los peces se mantengan a una profundidad mayor es cuando la temperatura del agua es menor que $28^{\circ} \mathrm{C}$, la profundidad del fondo es mayor que $30 \mathrm{~m}$, entre las 15:00 y las 3:00 h y la profundidad de la termoclina está entre 40 y $60 \mathrm{~m}$. Las hembras nadaron más profundo que los machos (fig. 5).

\section{DISCUSIÓN}

Se identificaron los movimientos horizontales y verticales de C. hippurus en BLP en relación con factores bióticos (sexo) y abióticos (temperatura del agua registrada por los transmisores acústicos, batimetría, profundidad de la termoclina y hora). Se marcaron ocho dorados juveniles, pero sólo se siguieron seis de ellos por un periodo máximo de $48 \mathrm{~h}$ en verano. Todos los individuos marcados permanecieron dentro de la BLP y sus movimientos horizontales se concentraron en una zona poco profunda $(1-80 \mathrm{~m})$ en el suroeste de la bahía y a temperaturas de entre 27 y $29^{\circ} \mathrm{C}$, lo cual coincide con las temperaturas preferenciales reportadas en otros trabajos (Palko et al. 1982, Campos et al. 1993, Massutí y MoralesNin 1995, Farrell et al. 2014).

Dos dorados marcados en el sureste de la BLP, un macho y una hembra, presentaron movimientos similares en cuanto a que casi cruzaron la bahía hacia el extremo opuesto. Los otros cuatro individuos se movieron en distintas direcciones, pero no se alejaron mucho de su sitio de captura. 


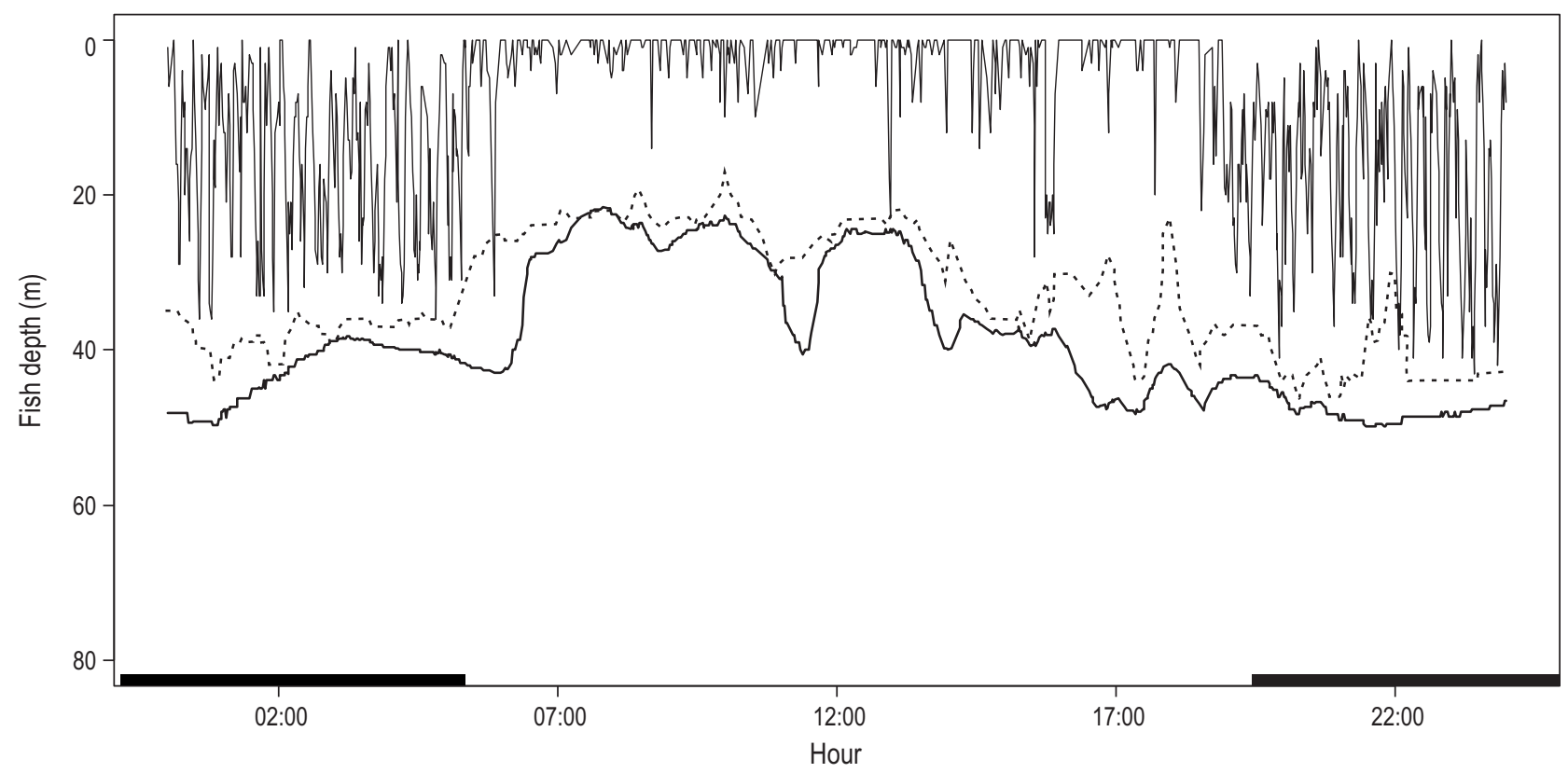

Figure 4. Fragment (24 h) of the time series of vertical movements along track 4: vertical lines, fish depth; bold line, bathymetry; dotted line, thermocline depth. The thick black bars on the $x$-axis indicate hours of darkness.

Figura 4. Fragmento de la serie de tiempo de los movimientos verticales para el seguimiento 4 durante 24 h: líneas verticales, profundidad del pez; línea oscura, batimetría; línea punteada, profundidad de la termoclina. Las barras negras sobre el eje $x$ indican horas de oscuridad.

The tagged dolphinfish undertook deep vertical immersions at night most likely to feed. Merten et al. (2014c) reported that the vertical immersions of adult male dolphinfish are related to the search and capture of epipelagic and mesopelagic prey, but they stress that their data may not be representative of the vertical movement strategy of females or juveniles. In the present study, however, juvenile males showed this behavior and juvenile females dove deeper than juvenile males. Given the limited information obtained in our study and that there are no feeding behavior data for C. hippurus in LPB, further research is needed to corroborate this relationship between vertical immersions and feeding behavior.

One limitation of this study was the number of individuals tagged. We recommend tagging a greater number of fish in future studies in order to be able to generate a database covering the annual cycle of $C$. hippurus and in particular the sport fishing season. Future research in LPB should contemplate studying the feeding habits of this species.

In summary, the majority of the movements of juvenile dolphinfish in LPB occurred in shallow near-shore areas, mainly between the surface and $30 \mathrm{~m}$ depth. While only a few individuals were tracked over a short period of time, we consider that this information could be taken into account to regulate dolphinfish catches in shallow areas of LPB in order to allow juveniles to reach sexual maturity and thus ensure that fishing activities are conducted in a sustainable manner in the region.
Merten et al. (2014a, 2014b) señalaron que la dirección y tasa de movimiento de los dorados que marcaron en el Atlántico varió según la latitud, longitud y distancia de la costa a la que fueron liberados, pero no indican una conclusión contundente sobre ese comportamiento.

En el presente estudio, los dorados marcados realizaron movimientos verticales en el estrato superior de la columna de agua comprendido entre la superficie y los $34 \mathrm{~m}$ de profundidad, por encima de la termoclina, cuando ésta fue detectada. Esto coincide con el carácter epipelágico del dorado y con lo reportado en otros trabajos que mencionan que este pez invierte gran parte de su tiempo en la superficie (Furukawa et al. 2011, Merten et al. 2014c). Se ha propuesto que esta preferencia de permanencia está relacionada con la distribución de su alimento en la columna de agua (Furukawa et al. 2011, Merten et al. 2014c), lo cual concuerda con estudios de hábitos alimenticios de la especie que indican que un importante componente de su dieta son presas epipélagicas que se distribuyen en estratos superficiales del mar (AguilarPalomino et al. 1998, Olson y Galván-Magaña 2002, TrippValdez et al. 2010). Aunado a lo anterior, la estratificación térmica en el mar genera una barrera física que es capaz de agregar verticalmente el alimento, incrementando la posibilidad de encontrar presas. Se ha sugerido que el estrato más importante para las interacciones tróficas entre las larvas de peces y zooplancton está en los primeros $30 \mathrm{~m}$ de profundidad, independientemente de donde se encuentre la termoclina (Gray y Kingsford 2003), y esta profundidad concuerda con 

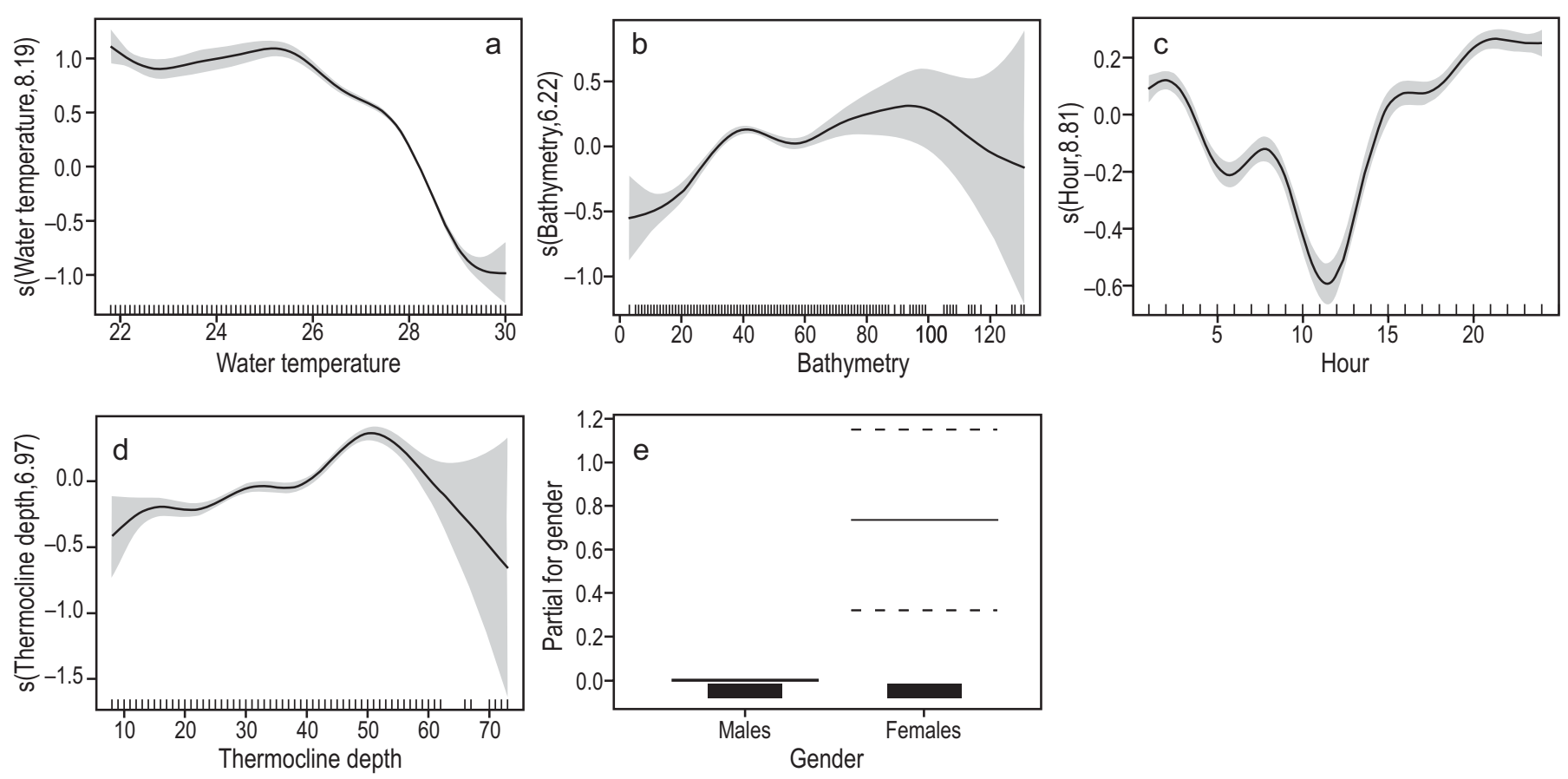

Figure 5. Generalized additive mixed models for vertical movements of Coryphaena hippurus. Plots show the effect of the explanatory variables (water temperature, bathymetry, hour, thermocline depth, and gender) on the response variable (fish depth). In (a-d), black tick marks above the $x$-axes indicate the distribution of data and the $y$-axes show the response variable on the scale of the linear predictor; the shaded areas indicate the standard error. In (e), the bars above the $x$-axis indicate the cumulative data for each gender, the thin horizontal lines indicate the value for the response variable (fish depth) on the linear predictor scale, and the horizontal dashed lines indicate the standard error.

Figura 5. Modelos aditivos generalizados mixtos de los movimientos verticales de Coryphaena hippurus. Las gráficas muestran el efecto de las variables explicativas (temperatura del agua, batimetría, hora, profundidad de la termoclina y género) sobre la variable de respuesta (profundidad del pez). En (a-d), las líneas verticales sobre los ejes $x$ indican la distribución de datos y los ejes $y$ muestran el valor de la variable de respuesta en la escala del predictor lineal; las áreas sombreadas indican el error estándar. En (e), las barras negras sobre el eje $x$ representan el acumulativo de los datos de cada género, las líneas horizontales delgadas representan el valor de la variable de respuesta (profundidad del pez) en escala del predictor lineal y las líneas horizontales discontinuas indican el error estándar.

\section{ACKNOWLEDGMENTS}

This study was supported by the National Council for Science and Technology (CONACYT, Mexico, project 133541). CHT is a recipient of a fellowship (CONACYT, no. 487113). We thank Mauricio Hoyos for lending the acoustic telemetry equipment; Armando Trasviña-Castro for lending the CastAway CTD; César Augusto Salinas-Zavala for lending the Ruskin XR-420 CTD; Jesús Bautista-Romero and Salvador Lluch-Cota for lending the GPSMAP 431s sounder; Guillermo García-Cortés, Jorge Cobos-Anaya, and Carlos Soto-Carrasco for building the hydrophone platform and developing other tagging and tracking material; Ira Fogel for editing services; and the captains Jorge Ángulo-Calvillo, Enrique Calvillo-Espinoza, Mario Cota-Castro, and Oswaldo Rodríguez-García and all the other people who helped to track the fish. The input of Raúl Martínez-Rincón (data analysis and R software use) and Patricia GonzálezZamorano (map depelopment and data analysis) is gratefully la profundidad a la que los dorados pasaron la mayor parte del tiempo durante el presente estudio $(30 \mathrm{~m})$.

Otros autores, han sugerido que la preferencia del hábitat de los dorados en aguas someras es una estrategia para evitar cambios bruscos de temperatura y así disminuir el gasto de energía al permanecer en condiciones isotérmicas arriba de la termoclina (Furukawa et al. 2011, 2014). En este estudio, el dorado cruzó ocasionalmente la termoclina (cuando ésta fue detectada), y este mismo comportamiento también fue reportado por Furukawa et al. (2011) y Merten et al. (2014c).

El dorado realizó inmersiones verticales profundas durante la noche. Es probable que este comportamiento esté relacionado con una estrategia de alimentación, pues de acuerdo con Merten et al. (2014c), este tipo de inmersiones verticales están relacionados con la búsqueda y captura de presas epipelágicas y mesopelágicas. El estudio de estos autores se centró en machos adultos e hicieron hincapié en que dicho comportamiento podría no ser representativo para hembras y juveniles; sin embargo, en este estudio los machos 
acknowledged. Finally, we thank the anonymous reviewers for their valuable comments that helped to improve this article.

English translation by Christine Harris.

\section{REFERENCES}

Aguilar-Palomino B, Galván-Magaña F, Abitia-Cárdenas LA, Muhlia-Melo AF, Rodríguez-Romero J. 1998. Feeding aspects of the dolphin Coryphaena hippurus Linnaeus, 1758 in Cabo San Lucas, Baja California Sur, Mexico. Cienc. Mar. 24(3): 253-265.

Alejo-Plata C, Díaz-Jaimes P, Salgado-Ugarte IH. 2011. Sex ratios, size at sexual maturity, and spawning seasonality of dolphinfish (Coryphaena hippurus) captured in the Gulf of Tehuantepec, Mexico. Fish. Res. 110: 207-216. http://dx.doi.org/10.1016/j.fishres.2011.04.008

Brill RW, Lutcavage ME. 2001. Understanding environmental influences on movements and depth distributions of tunas and billfishes can significantly improve population assessments. Am. Fish. Soc. Symp. 25: 179-198.

Campos JA, Segura A, Lizano O, Madrigal E. 1993. Ecología básica de Coryphaena hippurus (Pisces: Coryphaenidae) y abundancia de otros grandes pelágicos en el Pacífico de Costa Rica. Rev. Biol. Trop. 41: 783-790.

Cushman-Roisin B, Beckers JM. 2009. Introduction to Geophysical Fluid Dynamics. Physical and Numerical Aspects. Under contract with Academic Press, 773 pp.

[DOF] Diario Oficial de la Federación. 1995. Norma Oficial Mexicana NOM-017-PESC-1994 para regular las actividades de pesca deportiva en las Aguas de Jurisdicción Federal de los Estados Unidos Mexicanos. Tomo No. 15-19. México, DF.

Farrell ER, Boustany AM, Halpin PN, Hammond DL. 2014. Dolphinfish (Coryphaena hippurus) distribution in relation to biophysical ocean conditions in the northwest Atlantic. Fish. Res. 151: 177-190. http://dx.doi.org/10.1016/j.fishres.2013.11.014

Furukawa S, Kawabe R, Ohshimo S, Fujioka K, Nishihara GN, Tsuda Y, Aoshima T, Kanehara H, Nakata H. 2011. Vertical movement of dolphinfish Coryphaena hippurus as recorded by acceleration data-loggers in the northern East China Sea. Environ. Biol. Fish. 92: 89-99. http://dx.doi.org/10.1007/s10641-011-9818-y

Furukawa S, Tsuda Y, Nishihara GN, Fujioka K, Ohshimo S, Tomoe S, Nakatsuka N, Kimura H, Aoshima T, Kanehara H, Kitagawa T, Chiang W-C, Nakata H, Kawabe R. 2014. Vertical movements of Pacific bluefin tuna (Thunnus orientalis) and dolphinfish (Coryphaena hippurus) relative to the thermocline in the northern East China Sea. Fish. Res. 149: 86-91. http://dx.doi.org/10.1016/j.fishres.2013.09.004

Girard C, Dagorn L, Taquet M, Aumeeruddy R, Peignon C, Benhamou S. 2007. Homing abilities of dolphinfish (Coryphaena hippurus) displaced from fish aggregating devices (FADs) determined using ultrasonic telemetry. Aquat. Living Resour. 20: 313-321. http://dx.doi.org/10.1051/alr:2008005

Gray CA, Kingsford MJ. 2003. Variability in thermocline depth and strength, and relationships with vertical distributions of fish larvae and mesozooplankton in dynamic coastal waters. Mar. Ecol. Prog. Ser. 247: 211-224.

Ketchum JT, Hearn A, Klimley AP, Espinoza E, Peñaherrera C, Largier JL. 2014. Seasonal changes in movements and habitat preferences of the scalloped hammerhead shark (Sphyrna juveniles también presentaron este comportamiento y las hembras juveniles hicieron inmersiones más profundas que los machos juveniles. Dada la limitada información obtenida en este trabajo y que no se tienen datos del comportamiento alimenticio de $C$. hippurus en BLP, se sugiere realizar investigaciones que corroboren la relación entre sus movimientos verticales y su alimentación.

Una de las limitantes de este estudio fue el número de individuos marcados. Se sugiere que en futuras investigaciones se marque un mayor número de individuos y se genere una base de información que pueda abarcar todo el ciclo anual del dorado y la temporada de pesca deportiva. Por otro lado, en futuras investigaciones es recomendable hacer estudios de hábitos alimenticios de esta especie en BLP.

En resumen, los movimientos de los dorados juveniles dentro de BLP se concentraron cerca de la costa en áreas poco profundas, preferentemente entre la superficie y $30 \mathrm{~m}$ de profundidad. Aun cuando se siguieron pocos individuos y durante un corto periodo de tiempo, consideramos que esta información pudiera ser tomada en cuenta para regular la captura en zonas someras dentro de BLP para permitir que los juveniles alcancen la talla de madurez sexual y, por tanto, asegurar la sustentabilidad de la actividad pesquera de esta especie en esta región.

\section{Agradecimientos}

Agradecemos al Consejo Nacional de Ciencia y Tecnología (CONACYT) el proyecto 133541. CHT recibió una beca por parte del CONACYT (no. 487113). También agradecemos a Mauricio Hoyos el préstamo del equipo de telemetría acústica; a Armando Trasviña Castro el préstamo del CTD CastAway; a César Augusto Salinas Zavala el préstamo del CTD Ruskin-XR-420; a Jesús Bautista Romero y Salvador Lluch Cota el préstamo de la ecosonda GPSMAP 431s; a Guillermo García Cortés, Jorge Cobos Anaya y Carlos Soto Carrasco la elaboración de la base del hidrófono y otros materiales para el marcado y seguimiento; a los capitanes Jorge Ángulo Calvillo, Enrique Calvillo Espinoza, Mario Cota Castro y Oswaldo Rodríguez García; a Ira Fogel su servicio editorial; y a todas las personas que colaboraron en el seguimiento activo de los peces. Raúl Martínez Rincón contribuyó con sus comentarios y sugerencias en el análisis de datos y nos apoyó con el uso del software R. Patricia González Zamorano dio asesorías y sugerencias en la elaboración de mapas y análisis de datos. Agradecemos a los revisores anónimos su contribución para enriquecer este artículo. 
lewini) while refuging near an oceanic island. Mar. Biol. 161: 755-767.http://dx.doi.org/10.1007/s00227-013-2375-5

Madrid JV, Beltrán-Pimienta R. 2001. Length, weight and sex of the dolphin fish Coryphaena hippurus (Perciformes: Coryphaenidae) of the littoral of Sinaloa, Nayarit and Baja California Sur, Mexico. Rev. Biol. Trop. 49: 931-938.

Martínez-Rincón RO, Ortega-García S, Vaca-Rodríguez JG. 2009. Incidental catch of dolphinfish (Coryphaena spp.) reported by the Mexican tuna purse seiners in the eastern Pacific Ocean. Fish. Res. 96: 296-302. http://dx.doi.org/10.1016/j.fishres.2008.12.008

Massutí E, Morales-Nin B. 1995. Seasonality and reproduction of dolphinfish (Coryphaena hippurus) in the western Mediterranean. Sci. Mar. 59:357-364.

Merten W, Appeldoorn R, Hammond D. 2014a. Movements of dolphinfish (Coryphaena hippurus) along the U.S. east coast as determined through mark and recapture data. Fish. Res. 151: 114-121. http://dx.doi.org/10.1016/j.fishres.2013.10.021

Merten W, Appeldoorn R, Hammond D. 2014b. Spatial differentiation of dolphinfish (Coryphaena hippurus) movements relative to the Bahamian archipelago. Bull. Mar. Sci. 90: 849-864. http://dx.doi.org/10.5343/bms.2013.1078

Merten W, Appeldoorn R, Rivera R, Hammond D. 2014c. Diel vertical movements of adult male dolphinfish (Coryphaena hippurus) in the western central Atlantic as determined by use of pop-up satellite archival transmitters. Mar. Biol. 161: 1823-1834.

http://dx.doi.org/10.1007/s00227-014-2464-0

Nathan R, Getz WM, Revilla E, Holyoak M, Kadmon R, Saltz D, Smouse PE. 2008. A movement ecology paradigm for unifying organismal movement research. Proc. Natl. Acad. Sci. USA 105: 19052-19059. http://dx.doi.org/10.1073/pnas.0800375105

Olson RJ, Galván-Magaña F. 2002. Food habits and consumption rates of common dolphinfish (Coryphaena hippurus) in the Eastern Pacific Ocean. Fish. Bull. 279-298.

Palko BJ, Beardsley GL, Richards WJ. 1982. Synopsis of the biological data on dolphinfishes, Coryphaena hippurus and Coryphaena equiselis Linnaeus. FAO Fish Synop. 130: 1-28.
Papastamatiou YP, Meyer CG, Carvalho F, Dale JJ, Hutchinson MR, Holland KN. 2013. Telemetry and random-walk models reveal complex patterns of partial migration in a large marine predator. Bull. Ecol. Soc. Am. 94: 2595-2606.

R Core Team. 2014. R: A language and environment for statistical computing. R Foundation for Statistical Computing, Vienna, Austria, http://www.R-project.org/ [accessed May 2013].

Schaefer KM, Fuller DW, Block BA. 2011. Movements, behavior, and habitat utilization of yellowfin tuna (Thunnus albacores) in the Pacific Ocean off Baja California, Mexico, determined from archival tag data analyses, including unscented Kalman filtering. Fish. Res. 112: 22-37. http://dx.doi.org/10.1016/j.fishres.2011.08.006

Taquet M, Dagorn L, Gaertner JC, Girard C, Aumerruddy R, Sancho G, Itano D. 2007. Behavior of dolphinfish (Coryphaena hippurus) around drifting FADs as observed from automated acoustic receivers. Aquat. Living Resour. 20: 323-330. http://dx.doi.org/10.1051/alr:2008008

Tripp-Valdez A, Galván-Magaña F, Ortega-García S. 2010. Feeding habits of dolphinfish (Coryphaena hippurus) in the southeastern Gulf of California. Mexico. J. Appl. Ichthyol. 26: 578-582. http://dx.doi.org/10.1111/j.1439-0426.2010.01483.x

Varghese SP, Somvanshi VS, John ME, Dalvi RS. 2013. Diet and consumption rates of common dolphinfish, Coryphaena hippurus, in the eastern Arabian Sea. J. Appl. Ichthyol. 29: 1022-1029. http://dx.doi.org/10.1111/jai.12166

Wood SN. 2006. Generalized Additive Models: An Introduction with R. CRC Texts in Statistical Science, 384 pp.

Zúñiga-Flores MS, Ortega-García S, Rodríguez-Jaramillo MC, López-Martínez J. 2011. Reproductive dynamics of the common dolphinfish Coryphaena hippurus in the southern Gulf of California. Mar. Biol. Res. 7: 7677-7689. http://dx.doi.org/10.1080/17451000.2011.554558

Zuur AF, Ieno EN, Walker NJ, Saveliev AA, Smith GM. 2009. Mixed Effects Models and Extensions in Ecology with R. Springer Science+Business Media, New York, 574 pp.

Received July 2015, accepted October 2015. 